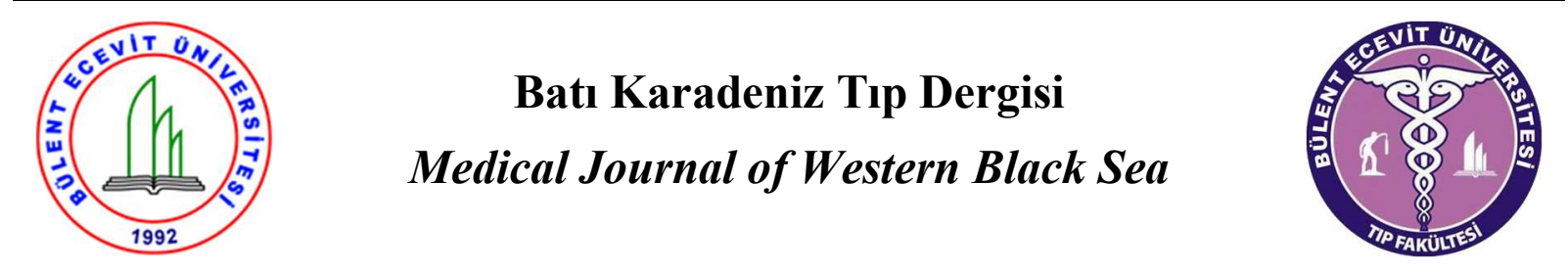

Olgu sunumu

\title{
Küçük Yaşta Geç Gelen Tehlikeli Bir Yabancı Cisim Aspirasyonu Olgusu
}

Hüseyin Fatih Sezer ${ }^{a}$, Abdulkerim Yılmaz ${ }^{a}$, Hakan Dayanır ${ }^{\text {a }}$

${ }^{a}$ Nyala Sudan Türkiye Eğitim ve Araştırma Hastanesi, Nyala, Sudan.

ORCID : Hüseyin Fatih Sezer 0000-0001-5812-7088, Abdulkerim Y1lmaz 0000-0002-3360-5837, Hakan Dayanır 00000003-2018-5818

\begin{tabular}{|c|c|}
\hline $\begin{array}{l}\text { M A K A L E } \\
\text { B İ L G İ S İ }\end{array}$ & Ö Z \\
\hline Gönderilme Tarihi: & \multirow{11}{*}{$\begin{array}{l}\text { Yabancı cisim aspirasyonu erken çocukluk çağında özellikle hayatın } \\
\text { ilk üç yılında meydana gelen ve yaşamı tehdit edebilecek ciddiyette } \\
\text { bir solunum yolu acilidir. Yabancı cisim aspirasyonları aspire edilen } \\
\text { yabancı cismin niteliğine, lokalizasyonuna, yaşa ve hastada bulunan } \\
\text { ek solunum yolu hastalıklara bağlı olarak çok farklı semptomlarla } \\
\text { karşımıza çıabilir. Tanı ve tedavide altın standart halen rijit } \\
\text { bronkoskopidir. Yazımızda } 14 \text { gün önce iğne aspirasyon öyküsü } \\
\text { sonrası tarafımızca kabul edilen } 15 \text { aylık çocuk hastadaki } \\
\text { tecrübemizi sunmaktayız. Özellikle keskin uçlu ve etrafındaki } \\
\text { dokulara zarar verebilecek yabancı cisimlere bir an önce müdahale } \\
\text { edilmelidir. Ayrıca hastanın yaşı küçüldükçe teknik olarak işlemin } \\
\text { zorluğu ve riski artacaktır. İ̧̧lem eğer mümkünse tecrübeli ellerde } \\
\text { yapılmalıdır. }\end{array}$} \\
\hline 2.11 .2018 & \\
\hline Revizyon: & \\
\hline 12.12 .2018 & \\
\hline Kabul: & \\
\hline 6.04 .2019 & \\
\hline Sorumlu Yazar: & \\
\hline Hüseyin Fatih Sezer & \\
\hline hfs.hfs@gmail.com & \\
\hline Anahtar Kelimeler: & \\
\hline $\begin{array}{l}\text { Yabancı cisim aspirasyonu, } \\
\text { bronkoskopi, türban iğnesi }\end{array}$ & \\
\hline
\end{tabular}




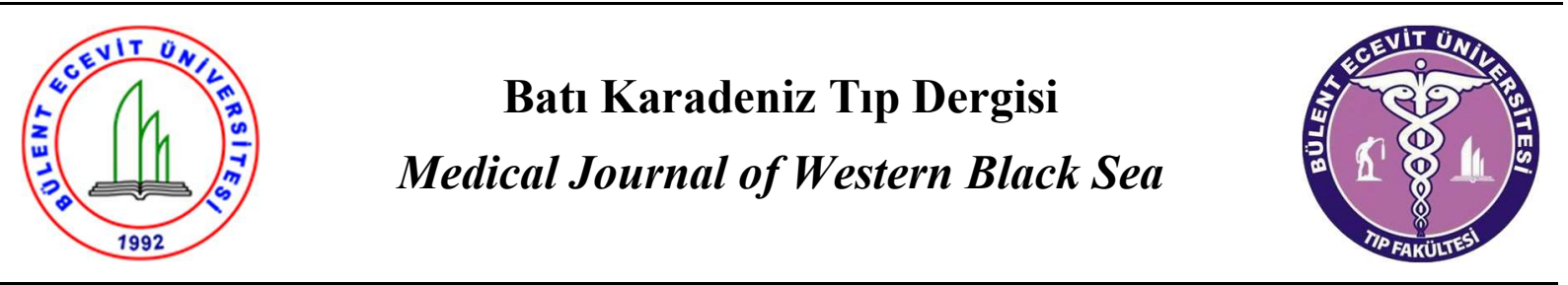

Case report

Doi: $10.29058 /$ mjwbs.2019.1.5

\section{A Dangerous Foreign Body Aspiration Case At Young Age Which Late Incoming}

Hüseyin Fatih Sezer ${ }^{a}$, Abdulkerim Yılmaz ${ }^{a}$, Hakan Dayanır ${ }^{a}$

a Nyala Sudan Turkey Training and Research Hospital, Nydala, Sudan.

A R T I C L E

\begin{tabular}{l} 
I N F O R M A T I O N \\
\hline Date of Submission \\
Revision: \\
12.12.2018 \\
Accepted: \\
6.04 .2019 \\
Correspondence Author: \\
Hüseyin Fatih Sezer \\
hfs.hfs@gmail.com \\
\hline Key Words: \\
Foreign body aspiration, rigid \\
bronchoscopy, scarf pin
\end{tabular}

\begin{abstract}
A B S T R A C T
Foreign body aspiration is a serious respiratory illness that can threaten life, particularly in early childhood, in the first three years of life. Foreign body aspirations depending on the nature of the aspirated body, its location, age and additional respiratory diseases, it may present with very different symptoms. Still the gold standard for diagnosis and treatment is rigid bronchoscopy. In our article, we present our experience in a 15-month-old child who was accepted after a history of needle aspiration for 14 days ago. In particular, foreign bodies that can damage tissues around the sharp edges should be immediately intervened. Also as the patient's age decreases, the difficulty and the risk of the procedure will increase. Operation should be done in experienced hands if possible.
\end{abstract}

C 2019 Bulent Ecevit University All rights reserved.

\section{Giriş}

Yabancı cisim aspirasyonları çocukluk çağında özellikle hayatın ilk üç yılında meydana gelen, yaşamı tehdit edebilecek ciddiyette bir solunum acilidir $(1,2)$. Çocukluk çağında kazara ölümlerin en sik sebeplerinden birisidir (3). Aspire edilen cismin niteliğine, lokalizasyonuna, yaşa ve hastada bulunan ek solunum yolu hastalıklara bağlı olarak çok farklı semptomlarla karşımıza çıkabilir $(1,2)$. Yabancı cismin solunum yolundan çıkartılması için yapılan girişimler oldukça riskli işlemlerdir ve altın standart uygulama rijit bronkoskopidir (1). Günümüzde solunum sistemi yabancı cisim aspirasyonlarına tüm teknolojik gelişmelere karşın, oluşabilecek komplikasyonlar nedeniyle tecrübeli kliniklerce bile tedirginlikle yaklaşılmaktadır (3). Yapılacak olan müdahalenin başarısını arttırmak ve oluşabilecek komplikasyonlarla karşılaşmamak adına erken teşhis, uygun ekipman, uygulanacak anestezi önemlidir (3). Yazımızda solunum yollarına göre bir hayli büyük boyutlu olan türban iğnesi aspire eden 15 aylık bir çocuğun rijit bronkoskopi ile tedavisini sunmaktayı.

\section{Olgu Sunumu}

14 gün önce türban iğnesi ile oynarken aniden öksürük ve geçici olarak yüzünde morarma şikayeti olan, sonrasında öksürük şikayeti devam eden 15 aylık kız çocuk tarafimıza başvurdu. Fizik muayenesinde vital bulguları stabildi. Sol hemitoraksta solunum seslerinde sağa göre bir miktar azalma mevcuttu. Çekilen posterior-anterior akciğer grafisinde sol ana bronştan karinaya doğru uzanım gösteren metalik yabancı cisim görüntüsü saptand1 (Resim 1).

Açlık süresi uygun olan hastaya genel anestezi altında rijit bronoskopi yapıldı. 3 numara rijit bronkoskopla işlem gerçekleştirildi. 


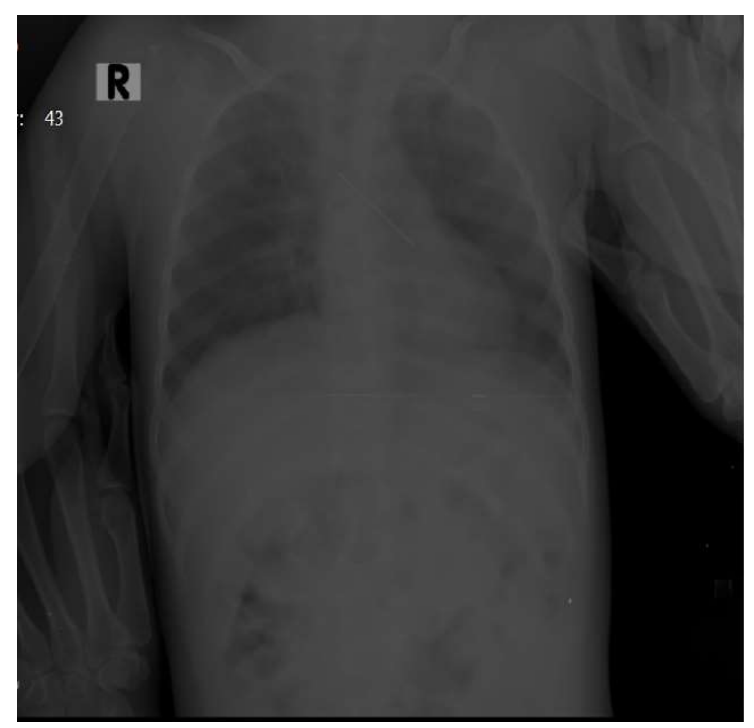

Resim 1: PA-Akciğer grafisi

Yabanc1 cismin keskin ucunun karinaya saplanarak granülasyon dokusu oluşturduğu görüldü. Uygun manevralarla keskin uçlu yabancı cisim komplikasyonsuz olarak çıkartıldı (Resim 2).

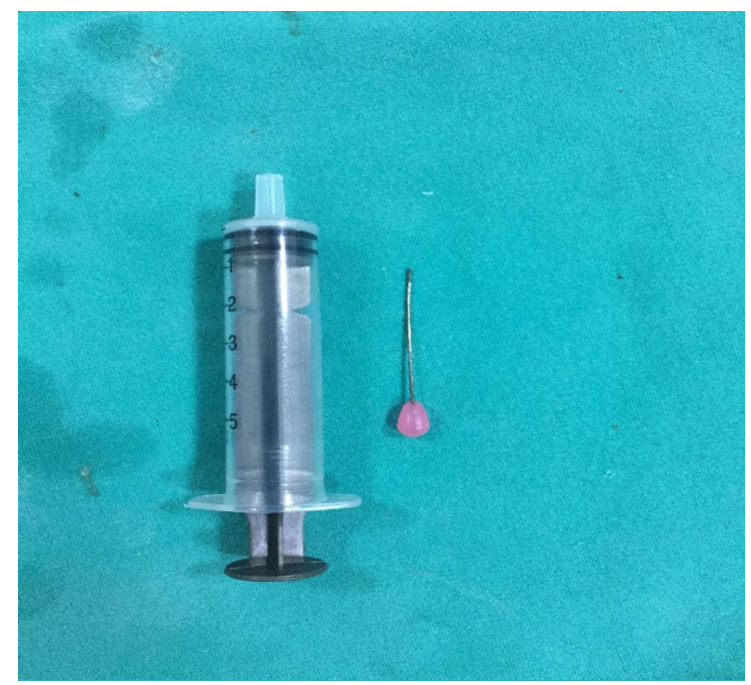

Resim 2: İğne

İşlem sonrasında 0 derece optikle işlem alanı kontrol edildi. Ayn 1 gece hastanede kalan hastaya parasetamol dışında medikal tedavi verilmedi ve ertesi gün taburcu edildi. Kontrolleri sorunsuz şekilde sürdürüldü.

\section{Tartışma}

Yabanc1 cisim aspirasyonları her ne kadar yetişkin yaşta da görülmesine rağmen sıklıkla 3 yaş altı çocuklarda görülmektedir $(1,2)$. Konu ile en çok kabul gören görüş bu yaş grubunda objeleri ağza alarak tanıma dürtüsünün aspirasyon riskini arttırmasıdır (4). Çocukluk yaş grubunda en sık çıkartılan aspire edilmiş yabancı cisimler genellikle besinsel organik cisimlerdir $(1,2)$. Beslenme alışkanlıklarına ve coğrafyaya bağlı olarak çocuk yaş grubunda findık, fistık, kuru fasülye, çekirdek, yemiş kabuğu en sı aspire edilen organik yabanc1 cisimlerdir $(1,2)$. Türban iğnesi aspirasyonu ile ilgili yapılan pek çok çalışmada en sık 14-16 yaş grubunda iğne aspirasyonuna rastlanmıştır (5).

Yabancı cisim aspirasyonları erken müdahale edilmesi gereken ciddi durumlardır. Öyle ki Türkiye'de yapılan bebek otopsileri ile ilgili bir çalışmada en sık ölüm nedeni anoksi ve anoksinin en s1k ikinci sebebi yabancı cisim aspirasyonu olarak bulunmuştur (6). Dokuya zarar verebilecek keskin uçlu yabancı cisimler, şişerek solunum yollarında rüptüre sebebiyet verebilecek yabanc1 cisimler, enfekte yabancı cisimler ve pil gibi dokuda erezyona sebebiyet vererek komplikasyon yaratabilecek yabancı cisimlerde aceleci davranılmalı ve bir an önce müdahale edilmelidir. Keskin uçlu yabancı cisimler penetre olduktan sonra solunum yoluna komşu mediastende yer alan organlara ya da vasküler yapılara hasar vererek ciddi komplikasyonlara yol açabilirler. Toraks içersine ilerleyerek ciddi operasyonlara gereksinim duyulmasına yol açabilirler. Hastamızda keskin uçlu olan türban iğnesi aspirasyonu mevcut olmasına ve karinaya penetre olmasina rağmen solunum yolunda oluşan granülasyon dokusu haricinde herhangi bir komplikasyonla karşılaşmadık. Sivri uçlu yabancı cisim aspirasyonlarına müdahale ederken keskin ucun solunum yollarına zarar vermemesine dikkat edilmelidir. Keskin uçlu yabancı cisim aspirasyonlarında yapılacak manüplasyonla keskin olan uç bronkoskopun içine alınarak çıkartılmadır. Yaşın küçülmesi ile beraber genişliği azalacak olan solunum yolları manüplasyonları sinırlayacak ve yapılacak girişimi zorlaştıracaktır.

Geniş çaplı çalışmalarda aspire edilen yabancı cisimlerin solunum yollarında saptandığ dağılımında belirgin farkla en sık sağ ana bronş gelir, daha sonra sırası ile sol ana bronş ve trakea gelmektedir (6-8). Hastamızda yabancı cisim sol ana bronşta gözlenmiştir. Yabancı cisim aspirasyonlarında hastaneye başvuru süresi sıklıkla ilk 6- 24 saattir $(1,2)$. Hastamızın hastaneye başvuru süresi 14 gün gibi geç bir süreydi. Buna karşın solunum yolunda oluşan granülasyon dokusu haricinde herhangi bir olumsuz sonuç oluşmaması büyük şanstı.

Sonuç olarak yabancı cisim aspirasyonlarının en sık ilk 3 yaşta görülmesi sebebi ile çocukların yaşam alanlarında kolay ulaşabilecekleri yerlerde aspire 
edebilecekleri nitelikte cisimler bulundurulmamalıdır. Ayrıca kamuoyunda farkındalık yaratacak çalışmalar ile geniş kitlelere ulaşılması çocuklarda görülen yabancı cisim aspirasyonu sıklığını azaltacaktır.

\section{Kaynaklar}

1. Liman ŞT, Eliçora A, Topçu S. Yabancı cisim aspirasyonları ve özofagus yabancı cisimleri. Toraks Cer Bült. 2012; 94-103.

2. Kolbakır F, Keçegil HT, Ankan A, Erk MK. Yabancı cisim aspirasyonları bronkoskopi yapılan 152 olgunun analizi. GKD Cer Derg. 1995; 2: $117-$ 120.

3. Akgül AG. Trakeobronşial yabancı cisimler. Yüksel M, Balcı AE, editörler. Göğüs Cerrahisi 'Kırmızı Kitap'. 2. Baskı. İstanbul: Nobel Tıp Kitapevleri; 2015; 1085-1091.

4. Black RE, Choi KJ, Syme WC, et al. Bronchoscopic removel of aspirated foreign bodies in children. Am J Surg. 1984; 148: 778- 781.

5. Sünnetçioğlu A, Karadaş S, Ebinç S. Keskin bir yabancı cisim aspirasyonu: Olgu sunumu. Van Tip Dergisi. 2013; 20: 183-185.

6. Eren S, Balc1 AE, Dikici B, et al. Foreign body aspirationin children: experience of 1160 cases. Ann Trop Pediatr 2003; 23: 31-37.

7. Eroğlu A, Kürkçüoğlu IC, Karaoğlanoğlu N, et al. Tracheobronchial foreign bodies: a 10 year experience. Ulus Trav Acil Cerr Derg. 2003; 9: 262266.

8. Arana A, Hauser B, Hachimi-Idrissi S, Vandenplas Y. Management of ingested foreign bodies in childhoodand review of the literature. Eur J Pediatr. 2001; 160: 468-472. 